\title{
Radiation-Induced Chromosomal Aberrations and Immunotherapy: Micronuclei, Cytosolic DNA, and Interferon-Production Pathway
}

\author{
Marco Durante ${ }^{1 *}$ and Silvia C. Formenti ${ }^{2}$ \\ ${ }^{1}$ Trento Institute for Fundamental and Applied Physics (TIFPA), National Institute for Nuclear Physics (INFN), University \\ of Trento, Trento, Italy, ${ }^{2}$ Department of Radiation Oncology, Weill Cornell Medical College, New York, NY, United States
}

Radiation-induced chromosomal aberrations represent an early marker of late effects, including cell killing and transformation. The measurement of cytogenetic damage in tissues, generally in blood lymphocytes, from patients treated with radiotherapy has been studied for many years to predict individual sensitivity and late morbidity. Acentric fragments are lost during mitosis and create micronuclei (MN), which are well correlated to cell killing. Immunotherapy is rapidly becoming a most promising new strategy for

OPEN ACCESS

Edited by:

Albert J. Fornace, Georgetown University,

United States

Reviewed by: Heng-Hong Li, Georgetown University, United States Dörthe Schaue, UCLA David Geffen School of Medicine, United States

*Correspondence: Marco Durante marco.durante@tifpa.infn.it

Specialty section: This article was submitted to Radiation Oncology, a section of the journal

Frontiers in Oncology

Received: 09 March 2018 Accepted: 14 May 2018 Published: 29 May 2018

Citation:

Durante M and Formenti SC (2018) Radiation-Induced Chromosomal Aberrations and Immunotherapy: Micronuclei, Cytosolic DNA, and Interferon-Production Pathway.

Front. Oncol. 8:192. doi: 10.3389/fonc. 2018.00192 metastatic tumors, and combination with radiotherapy is explored in several pre-clinical studies and clinical trials. Recent evidence has shown that the presence of cytosolic DNA activates immune response via the cyclic GMP-AMP synthase/stimulator of interferon genes pathway, which induces type I interferon transcription. Cytosolic DNA can be found after exposure to ionizing radiation either as $\mathrm{MN}$ or as small fragments leaking through nuclear envelope ruptures. The study of the dependence of cytosolic DNA and $\mathrm{MN}$ on dose and radiation quality can guide the optimal combination of radiotherapy and immunotherapy. The role of densely ionizing charged particles is under active investigation to define their impact on the activation of the interferon pathway.

Keywords: radioimmunotherapy, chromosome aberrations, micronuclei, cyclic GMP-AMP synthase, stimulator of interferon genes, particle therapy

\section{INTRODUCTION}

The analysis of chromosome aberrations (CA) has been one of the first tools to study the mechanisms of radiation action in living cells. Being relatively easy to observe and measure, early cytological investigations focused on asymmetrical rearrangements observed at the first mitosis after irradiation. The classical theory of radiation action, developed by Douglas Lea almost a century ago (1), is largely based on CA data, and its basic principles are considered still valid today. With the discovery of fluorescence in situ hybridization (FISH), radiation cytogenetics entered in the "color" era (2) and many more details on the formation of radiation-induced CA could be discovered, especially those involving symmetrical-type rearrangements, complex-type exchanges, and intrachromosomal exchanges. Studies on molecular pathways of DNA damage response have largely increased our understanding of the link between the initial DNA lesions, especially double-strand breaks (DSB), and the formation of CA (3).

Chromosome aberrations can be easily assessed in peripheral blood lymphocytes (PBL), stimulated to grow ex vivo, and for this reason they are a useful tool for radiation biodosimetry (4). It is indeed quite easy to get blood samples both from radiation workers (in case of a nuclear accident) 
or from patients treated with radiotherapy. The MN assay can also be performed in automatic or semi-automatic image analysis system $(5,6)$, making possible the scoring of many thousands of cells in short time. For many years, dicentrics and MN measurements have been used for biodosimetry. With FISH-painting, it became possible to look at stable CA and, therefore, to perform retrospective biodosimetry. Inter-individual variability in measurements of radiation-induced CA in PBL (7) has triggered many efforts to investigate ex vivo measurements as predictive assays of individual susceptibility to radiation therapy. Despite these high expectations, the results have been disappointing, since no clear correlation with individual toxicity could be established $(8,9)$. CA in PBL are also considered an early biomarker of late cancer risk. However, even if this observation is supported by molecular epidemiology studies (10), it only applies to large population studies and has little application to individual prediction of risk. Therefore, with the recent onset of precision medicine based on genome sequencing in radiotherapy $(11,12)$, CA studies became less appealing and somehow regarded as "old style" compared to the modern genome-wide association studies and epigenetic techniques.

Recently, the extensive experience from radiation-induced CA studies has been re-visited in a completely different context: immunotherapy. Immunotherapy is nowadays generally acknowledged as a most promising strategy for cancer treatment, including the setting of metastatic disease $(13,14)$. Because of the pivotal trial in metastatic melanoma, innumerable clinical trials are testing immune checkpoint blockade agents in multiple solid tumors. In locally advanced and metastatic solid tumors, immunotherapy is often combined with a local treatment (15). The combination of radiotherapy and immunotherapy (radioimmunotherapy) is particularly promising, because radiation elicits immune response pathways that can boost the action of drugs that either stimulate the immune system or block immune suppressive signals (16-22).

\section{DNA DAMAGE AND INNATE IMMUNITY}

The molecular signaling linking the initial radiation effects (DNA damage and CA) to immune stimulation has been recently discovered in studies of autoimmune diseases (23). The cyclic GMP-AMP synthase (cGAS) is a cytosolic DNA sensor that, upon binding double-stranded DNA (dsDNA), activates the stimulator of interferon genes (STING) endoplasmatic reticulum adaptor protein $(24,25)$. STING induces type I interferon and other cytokines, key mediators of BAFT-3 dendritic cells recruitment for cross presentation and immune response $(26,27)$, and it is, therefore, important for successful cancer immunotherapy $(28,29)$. In murine models STING activation in the tumor microenvironment and/or in the cancer cells enhances radiationinduced antitumor immunity $(30,31)$ and can prevent radiationinduced acute intestinal tissue injury (32). It has to be noted, however, that the role of the STING activation in immune response can be multi-faceted. Radiation-induced STING activation may be immunosuppressive due to myeloid-derived suppressor cell infiltration (33), and may promote invasion and metastasis by upregulating the NF- $\mathrm{KB}$ pathway (34). Notwithstanding the complexity of the pathways and the possibility of opposite effects, cytosolic sensors of nucleic acids are extensively studied as targets for immunotherapy (35).

But how can dsDNA leak into the cytoplasm? The mechanism may actually be the one well known from radiation-induced CA studies: formation of micronuclei (MN).

\section{MICRONUCLEI}

Micronuclei are small nuclei found in the cytoplasm of mammalian cells (Figure 1). They can originate either by acentric fragments or whole chromosome loss at anaphase (36). Spontaneous $\mathrm{MN}$ are found at low level in different normal human tissues and cells, and are produced by genotoxic stress and exposure to clastogenic or aneugenic agents. $\mathrm{MN}$ are generally scored in cytochalasin-blocked binucleated $(\mathrm{BN})$ cells. With the cytochalasin-B treatment, MN can be scored in cells attempting their first mitosis (37). The two nuclei of the blocked cell can be joined by a nucleoplasmic bridge (NPB) in the presence of dicentrics or polycentric aberrations (38). Following exposure to ionizing radiation, $\mathrm{CA}$ are formed including acentric fragments (Figure 2) originating from asymmetrical intra-arm (interstitial deletions) or inter-arm (centric rings) intrachanges, asymmetrical interchanges (dicentrics), terminal deletions, or incomplete exchanges (39). Using conventional, solid staining in Giemsa, observed interstitial deletions in human PBL at the first mitosis after radiation exposure are about $60 \%$ of the dicentrics (40). However, fragments from rings or dicentrics are rather large, while many interstitial deletions are small, often below the detection limit of many cytogenetic techniques $(41,42)$. The recent method of directional genomic hybridization has uncovered a large number of small inversions $(42,43)$, the symmetrical counterpart of interstitial deletions. It is also known that ionizing radiation induce chromosome missegregation and, therefore, aneuploidy $(44,45)$. Micronuclei containing whole chromosomes can be easily detected using FISH with

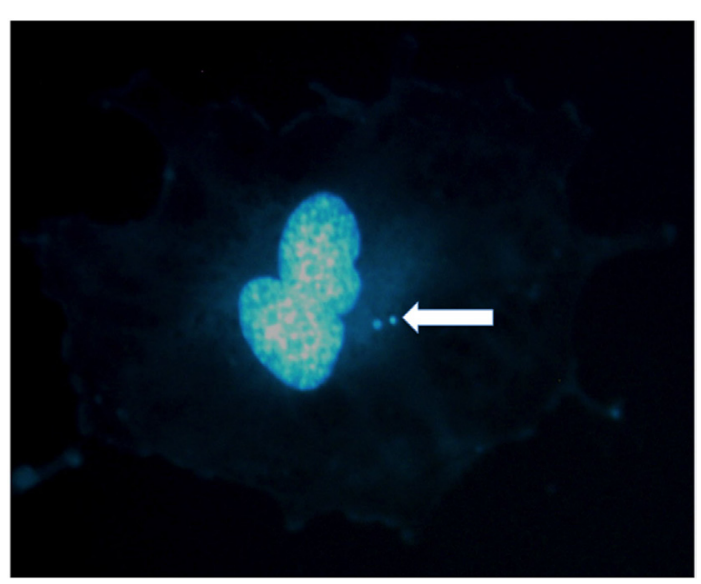

FIGURE 1 | Micronuclei in the cytoplasm of a human umbilical vein endothelial cell exposed to X-rays. Two micronuclei are visible in this binucleated cell stained in DAPI. Photo courtesy of Dr. Alexander Helm. 


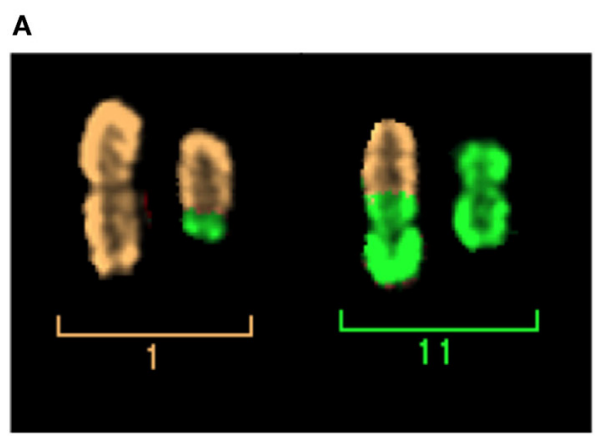

B

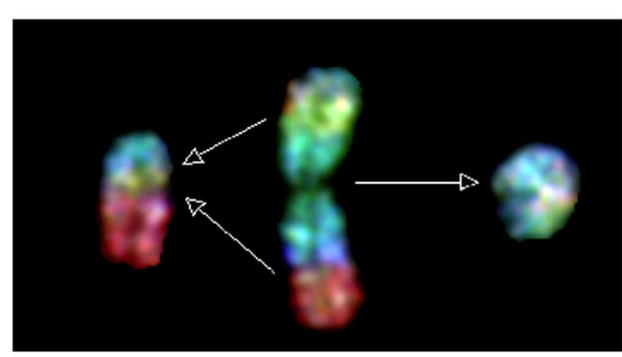

C

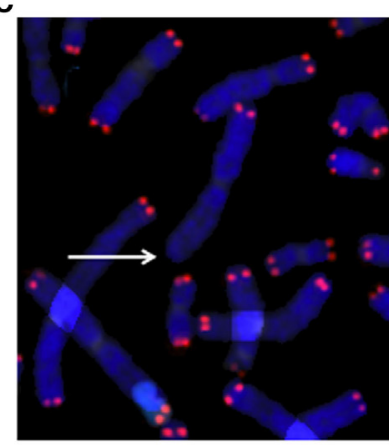

D

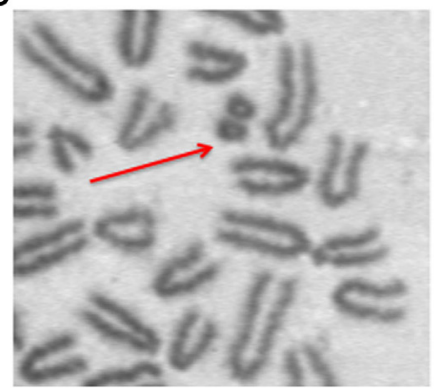

FIGURE 2 | Micronuclei originate from radiation-induced chromosome aberrations. Acentric fragments in irradiated cells are shown in this panel. (A) A dicentric chromosome and associated acentric fragment between chromosome 1 and 11 in a human peripheral blood lymphocytes exposed to heavy ions. Image visualized by $\mathrm{mFISH}$. (B) Formation of a radiation-induced ring and its associated acentric fragment visualized by $\mathrm{R} \times \mathrm{FISH}$ (cross-species color banding). A normal chromosome 3 is shown in the middle, the centric ring on the right, and the acentric fragment resulting from the joining of the two residual fragments in the two different arms on the left. (C) A terminal deletion induced by heavy ions in human lymphocytes. The lack of telomere signal indicates that a fragment has been lost. (D) An interstitial deletion at the first mitosis following exposure of G0-phase mouse fibroblasts to X-rays. Interstitial deletions appear often as double minutes. In this photomicrograph of Giemsa-stained mitotic chromosomes, it is clear their nature of acentric rings resulting from the asymmetrical intra-arm intrachange.

centromeric DNA probes or antikinetochore-antibody (CREST) probes. While the baseline frequency of CREST-positive MN is rather high (about $40 \%$ of the total background $\mathrm{MN}$ ), the vast majority of radiation-induced $\mathrm{MN}$ are CREST-negative (46), suggesting that the main mechanism for the formation of radiation-induced $\mathrm{MN}$ is the formation of asymmetrical-type CA by DNA DSB misrepair.

\section{MICRONUCLEI AND CYTOSOLIC DNA}

If the damaged cell go through mitosis, $\mathrm{MN}$ can be transmitted to the daughter cells and thus persist much longer (47), especially in cells with mutated or lost p53 (48), as most cancer cells. Defective and delayed DNA replication occurs within MN, with impaired checkpoint arrest, leading to pulverization of the incompletely replicated MN DNA in the ensuing mitosis (49). This mechanism may explain the generation of chromothripsis (literally "chromosome shattering"), a single catastrophic event leading to multiple, up to thousands, chromosomal rearrangements (50-53).

Cytosolic DNA in MN can explain the activation of the cGAS/ STING pathway following exposure to clastogenic agents and, specifically, ionizing radiation. In fact, relocalization of cGAS to $\mathrm{MN}$ following mitotic progression triggers inflammatory signaling (54) and interferon-stimulated gene expression is activated in cells containing $\mathrm{MN}$ (55). cGAS can sense the dsDNA in the cytosol because the MN nuclear envelope (NE) often collapses during interphase in cancer cells, due to defects in nuclear lamina assembly (56). Recently, using several human and murine carcinoma cells, it has been shown that the concentration of cytosolic dsDNA increases with radiation dose up to about 15-18 Gy, but then decrease at higher doses, probably because it is degraded by the activation of the DNA exonuclease Trex1 (31). Finding the correct dose for induction of sufficient dsDNA and immunestimulatory signals via cGAS/STING pathway versus Trex1 activation (57) may be a key step to select optimal radiotherapy protocols during immunotherapy. Insights can be derived from the analysis of radiation dose- and quality-dependence of MN induction.

\section{RADIATION-INDUCED MICRONUCLEI}

Background yield of MN shows large variation among cell types and, in human PBL, significant inter-individual variability, ranging 0-40 per 1,000 BN cells (4). The dose-response curve in the range $0-4 \mathrm{~Gy}$ for the induction of $\mathrm{MN} / \mathrm{BN}$ is generally considered linear-quadratic for low-linear energy transfer (LET) X- or $\gamma$-rays (36) and becomes linear for high-LET neutrons (58), protons $(59,60), \alpha$-particles (61), and heavy ions (62) (Figure 3). This behavior reflects the dose-response curve for the induction of CA (4). From these classical data, more dsDNA is expected to be 
produced by increasing dose. At the same dose, high-LET charged particles are more effective in the induction of MN (63-67) than sparsely ionizing X-rays. The relationship between relative biological effectiveness (RBE) and LET, based on the data available in the literature, is shown in Figure $\mathbf{4}$ and has the typical trend observed for other endpoints, such as CA (68), mutations (69), cells killing (70), or neoplastic transformation (71). Also consistent with the sparing effect observed at low dose rate for most cellular endpoints, $\mathrm{MN}$ yields are reduced for chronic compared to acute exposure $(72,73)$. MN have been often measured in PBL from individuals exposed to radiation because of nuclear accidents or for cancer therapy. In radiotherapy patients, the increase of $\mathrm{MN}$ in $\mathrm{PBL}$ is generally linearly correlated to the number of fractions (74-76) and strongly depends on the irradiated volume during the treatment (77).

However, data in Figures $\mathbf{3}$ and $\mathbf{4}$ are relative to MN frequency per BN cell using the cytokinesis-block method. The time between irradiation, supplementation of cytochalasin-B, and harvest, are selected to block as many cells as possible reaching the first mitosis, and depends on the cell type. In PBL, cytochalasin-B is added $24 \mathrm{~h}$ after irradiation and cultures are fixed $72 \mathrm{~h}$ after irradiation with some differences among laboratories (78). The measured $\mathrm{MN}$ yield is normalized to the cytokinesis-blocked BN cells, i.e., those reaching mitosis. The problem is complicated by the cell-cycle delay and checkpoint block. Cells with less DNA damage tend to arrive in mitosis earlier than those heavily damaged (79), and the effect is stronger for densely ionizing (high-LET) radiation, where the dose distribution is non-uniform and the cell-cycle delays more

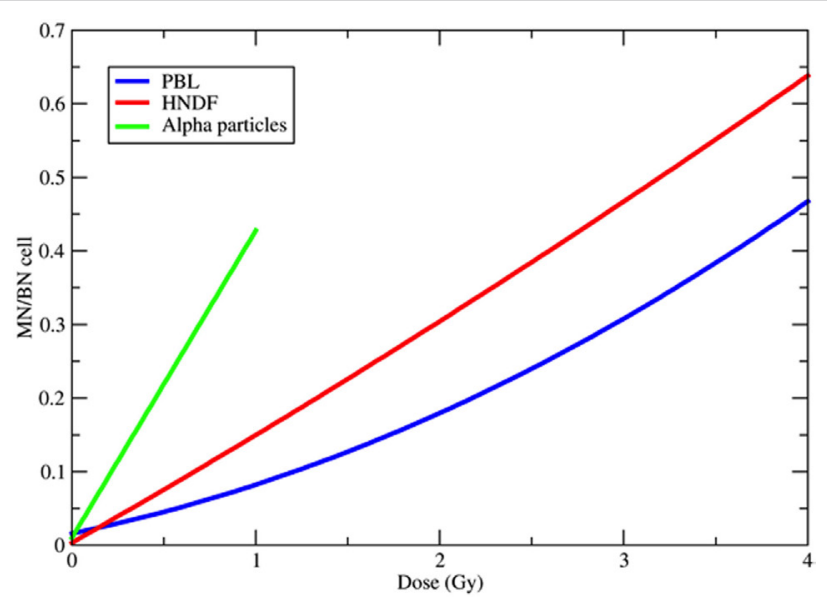

FIGURE 3 | Examples of dose-response curves for the induction of micronuclei (MN) per binucleated (BN) cell. The blue curve is the weighted mean of the calibration curves used in 10 different European laboratories for MN biodosimetry using human peripheral blood lymphocytes (PBL) within the RENEB project (78). The equation is $Y=0.016+0.0508 \cdot D+0.0155 \cdot D^{2}$, where $Y$ is the frequency of MN per BN cell and $D$ the ${ }^{60} \mathrm{Co} \gamma$-ray dose in gray. The red curve refers to human neonatal dermal fibroblasts (HNDF) exposed to ${ }^{60} \mathrm{Co} \gamma$-ray (59). The equation used by the authors to fit their data was $Y=0.033+0.1423 \cdot D+0.0041 \cdot D^{2}$. The green line refers to human PBL exposed to ${ }^{239} \mathrm{Pu} \alpha$-particles (61). Data points (all at doses $<1 \mathrm{~Gy}$ ) were fitted by the function $Y=0.098+0.418 \cdot D$. pronounced $(80,81)$. Consistently, the yield of $\mathrm{MN}$ induced by $\alpha$-particles or neutrons was indeed found to increase by increasing the harvest time from 72 to $120 \mathrm{~h}$ (82). This leads to a downward curvature in the dose-response curve when $\mathrm{MN}$ are measured at the same harvest time, and the decrease in BN cells carrying MN occurs at lower doses for high-LET compared to low-LET radiation $(63,67)$ (Figure 5).

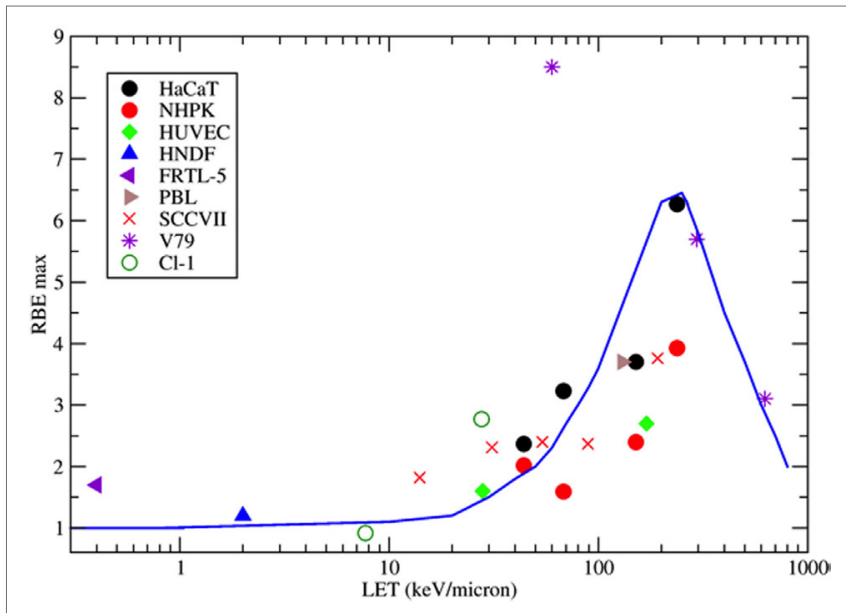

FIGURE 4 | Collection of measured relative biological effectiveness (RBE) data for the induction of $\mathrm{MN}$ per BN cell after exposure to protons, $\alpha$-particles, or energetic heavy ions. RBE was calculated as the ratio of the initial slope of the dose-response curves for ions and photons as measured by the same authors. Different symbols refer to different cell types. $\mathrm{HaCaT}$ = spontaneously immortalized adult human keratinocytes (63); $\mathrm{NHPK}=$ normal human neonatal epidermal keratinocytes (63); HUVEC = human umbilical vein endothelial cells (67); HNDF = human neonatal dermal fibroblasts (59); FRTL-5 = Fischer rat thyroid cell line (60); $\mathrm{PBL}=$ human peripheral blood lymphocytes (61); SCCVIII = mouse squamous cell carcinoma (64); V79 =Chinese hamster fibroblasts (62); $\mathrm{Cl}-1=$ Chinese hamster fibroblasts (46). The blue line is a guide for the eye.

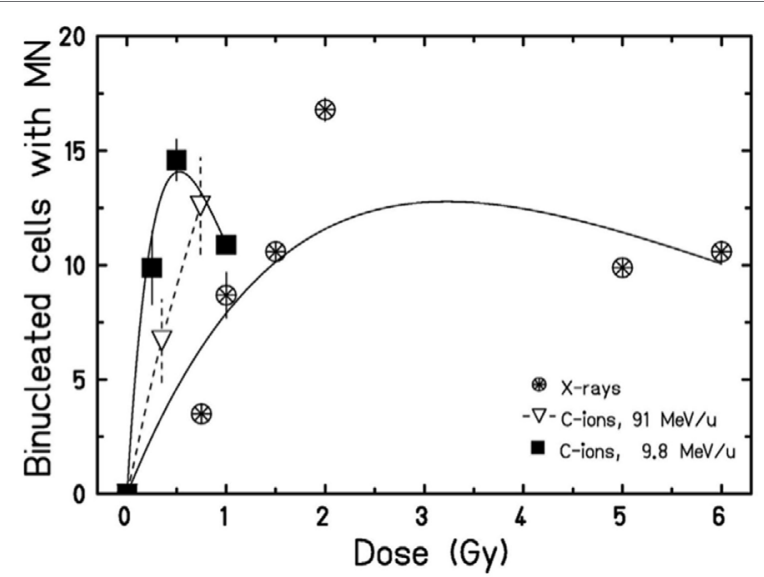

FIGURE 5 | Dose-response curves for the induction of MN in HUVEC cells exposed to X-rays or accelerated carbon ions at two different energies. A curvature at high doses can be observed. Figure reproduced with permission from Ref. (67). 


\section{FRACTIONATION AND RADIATION QUALITY IN IMMUNE RESPONSE}

In the context of radioimmunotherapy, these data have an impact on the protocol to be used to optimize the immune response. A general trend in radiotherapy is the use of hypofractionation (83-85) and accelerated charged particles (86-88). In both cases, the combination with immunotherapy may be advantageous compared to conventional, fractionated X-ray therapy $(89,90)$. A few pre-clinical studies address the impact of the dose/fraction on the immune response (91-93). In a poorly immunogenic mouse tumor models not expressing model antigens, Dewan et al. (94) observed a strong abscopal response using anti-CTLA- 4 antibody combined to fractionated $(3 \times 8 \mathrm{~Gy}) \mathrm{X}$-rays, while the effect was lost with a single dose of 20 Gy. Similarly, Schaue et al. (95) found that a medium size dose per fraction $(7.5 \mathrm{~Gy})$ was more effective than a single high dose of $15 \mathrm{~Gy}$ in eliciting immune response in a mouse melanoma model. Within the cGAS/STING pathway discussed above, the data on micronuclei seem to indicate a complex radiation dose- and quality-dependence. If $\mathrm{MN}$ elicit the proinflammatory immune response (96), the classical radiobiology data described above can now help to guide the radiotherapy schedule. Very high doses delivered in single fractions may reduce the yield of micronuclei (Figure 5), or greatly delay their appearance. Trex1 is involved in the resolution of NPB caused at mitosis by dicentric chromosomes (97), and is, therefore, activated at high doses. Trexl activation at high doses removes available dsDNA from the cytosol, and will then inhibit the cGAS/STING activation (98). However, Vanpouille-Box et al. (31) found a threshold for the Trex-1 activation around 8-15 Gy, suggesting that quite large dose/fraction compared to the conventional 2 Gy/fraction, can be used in combined treatments. Defining the right balance between the inductions of $\mathrm{MN} / \mathrm{dsDNA}$ without triggering the suppressive mechanisms elicited at high doses appears to be specific for each tumor type (93). In fractionated radiotherapy, cancer cells containing $\mathrm{MN}$ can be exposed and, because of the defective DNA repair mechanism in the MN (50), the MN DNA will be cut in smaller fragments. This can also affect the activation of the STING-interferon pathway, because cGAS catalytic activity depends on the dsDNA size $(99,100)$.

Similar arguments apply to fractionation with particle therapy. Charged particles are more effective in the induction of MN (Figure 4) but also induce more severe mitotic delays than $\mathrm{X}$-rays. Fractionation reduces the yield of MN induced by X-rays compared to single fractions, but the sparing effect is reduced for high-LET radiation, and in fact no difference in $\mathrm{MN}$ frequency was observed in PBL exposed to $3 \mathrm{~Gy}$ fast neutrons delivered in a single fraction or in two equal fractions (101).

\section{NE RUPTURES}

Can nuclear DNA fragments leak in the cytoplasm independently of the formation of MN? Small dsDNA is found in the cytoplasm after exposure of thyroid cells to electric pulses $(102,103)$. It is well known that densely ionizing radiation induces a high fraction of small DNA fragments (104-108), below the resolution of optical microscopy. The Ku-heterodimer, essential for the non-homologous end-joining (NHEJ) repair pathway, may fail binding fragments $<40 \mathrm{bp}(109)$ leaving them essentially free to drift in the cell. Supporting this hypothesis, the RBE of high-LET heavy ions is $\sim 1$ in $\mathrm{Ku}^{-/-}$(NHEJ-deficient) cells (110), suggesting that the higher effectiveness of heavy ions in the induction of cell inactivation or CA is due to the inability of NHEJ to cope with very small fragments. While $\mathrm{MN}$ formation requires the cell to enter mitosis, the question is whether small DNA fragments can leak in the cytoplasm during interphase. This may be possible via transient NE rupture, a loss of nuclear integrity in interphase leading to mislocalization of nuclear and cytoplasmic proteins (111). NE rupture is enhanced by loss of p53 and $\mathrm{Rb}$ genes (112), and is, therefore, more common in cancer cells. Chromatin herniation and DNA DSB are found in the NE opening sites, which are rapidly repaired to prevent cell death (113). Interestingly, loss of the $\mathrm{NE}$ is observed during cancer cell migration and leads to cGAS accumulation at the rupture sites (114). Ionizing radiation promotes cell migration at sub-lethal doses (115-118). The linker of nucleoskeleton and cytoskeleton complex is responsible for both radiation-induced cell migration (119) and NE ruptures (120). Therefore, NE ruptures may become more likely following radiation exposure.

\section{MITOCHONDRIAL DNA}

Cytosolic DNA is of course naturally present in mammalian cells, within the mitochondria. Mitochondria are the energy factories of the cells, and contain their own DNA (mtDNA), which encodes for some of the key genes in the electron transport chain. Cytosolic leakage of mtDNA also results in activation of the cGAS-STING pathway $(121,122)$. Can radiation-induced damage to mtDNA trigger the immune response? It is well known that mitochondria play an important role in radiation-induced effects. Mitochondria are sources of reactive oxygen species (ROS) and play a major role in the induction and persistence of oxidative stress following exposure to radiation $(123,124)$. They are also involved in non-targeted radiation effects $(125,126)$, suggesting their involvement in systemic responses such as post-radiation immunity. However, mtDNA is not a primary target of radiation. Recent track structure simulations suggest that the probability of DSB induction in mtDNA is very low at moderate doses, around $0.03 \%$ at $1 \mathrm{~Gy}$ for either $\gamma$-rays or densely ionizing radiation (127). The involvement of mitochondria in late radiation effects is more likely to be an indirect consequence of the ROS generation after irradiation and of the nucleus-mitochondria signaling pathway. Nevertheless, it is possible that mtDNA can leak in the cytosol following a direct hit from a charged particle. Using a particle microbeam, Walsh et al. (128) reported a rapid loss of membrane potential following focused irradiation of mitochondria with protons or C-ions. This result suggests that high energy deposition in the mitochondria can induce DSB in mtDNA and mitochondrial membrane damage. Even if depolarization was obtained only by focusing over 80 ions on the mitochondria (128), the results suggest that direct hits of heavy ions in the mitochondria may lead to leakage of mtDNA in the cytosol. 


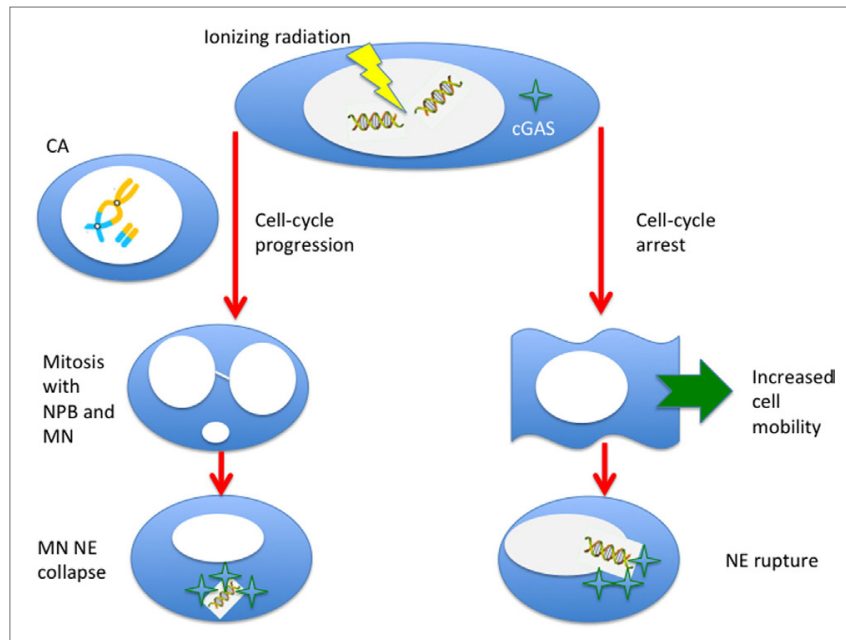

FIGURE 6 | lonizing radiation can induce cytosolic DNA, thus triggering the cyclic GMP-AMP synthase (cGAS)/stimulator of interferon genes (STING) pathway, in two different ways. If cells progress to mitosis carrying chromosome aberrations, MN (from acentric fragments) can be produced at the first mitosis along with nucleoplasmic bridges (NPB, from dicentrics). These micronuclei can be incorporated in the cytoplasm of the daughter cells and, following the collapse of the nuclear envelope (NE), can be sensed by the cGAS. Alternatively, even if the cell is blocked or delayed in the cell-cycle, radiation-induced DNA fragments can leak through a damaged NE. This effect can be more likely for very small fragments induced by densely ionizing radiation, and NE rupture can be triggered by the enhanced mobility of the cells following radiation exposure.

\section{CONCLUSION}

The link between immunotherapy and radiation-induced CA and MN is an example of "new tricks for old dogs." First observed almost one century ago [see Ref. (1), chapter VI], they have been studied extensively mostly for biological dosimetry and as surrogate markers of cell death. The recently discovered role of cytoplasmic DNA sensing in immunity, derived from infectious

\section{REFERENCES}

1. Lea DE. Action of Radiations on Living Cells. New York, NY: Cambridge University Press, The Macmillan Company (1947).

2. Durante M. Radiation cytogenetics: the color revolution. In: Cigna AA, Durante M, editors. Radiation Risk Estimates in Normal and Emergency Situations NATO Security through Science Series. Dordrecht, Netherlands: Springer (2016). p. 243-52.

3. Durante M, Bedford JS, Chen DJ, Conrad S, Cornforth MN, Natarajan AT, et al. From DNA damage to chromosome aberrations: joining the break. Mutat Res (2013) 756:5-13. doi:10.1016/j.mrgentox.2013.05.014

4. International Atomic Energy Agency. Cytogenetic Dosimetry: Applications in Preparedness for and Response to Radiation Emergencies. Vienna: International Atomic Energy Agency (2011)

5. Decordier I, Papine A, Plas G, Roesems S, Vande Loock K, Moreno-Palomo J, et al. Automated image analysis of cytokinesis-blocked micronuclei: an adapted protocol and a validated scoring procedure for biomonitoring. Mutagenesis (2008) 24:85-93. doi:10.1093/mutage/gen057

6. Bahreyni Toossi MT, Azimian H, Sarrafzadeh O, Mohebbi S, Soleymanifard S. Automatic detection of micronuclei by cell microscopic image processing. Mutat Res (2017) 806:9-18. doi:10.1016/j.mrfmmm.2017.07.012

7. Pajic J, Rakic B, Rovcanin B, Jovicic D, Novakovic I, Milovanovic A, et al. Interindividual variability in the response of human peripheral blood lymphocytes disease studies, makes this experience now tremendously useful to understand the mechanism that underlie synergy of radiotherapy and immunotherapy in cancer treatment. Radiation is an S-phase-independent clastogen, and is a powerful inducer of $\mathrm{MN}$ for cells exposed in all cell-cycle phases. Moreover, radiation enhances cell mobility, and the cytoskeleton stress during motion can produce ruptures in the NE and additional leak of DNA fragments. Therefore, there seem to be at least two pathways for the production of cytosolic DNA by radiation (Figure 6): the first is dependent on cell-cycle progression and MN formation, the second on mobility and NE ruptures. A third possibility may arise from direct damage of mitochondria. The dose-response curve for MN induction is well characterized, and saturation at high doses by Trex1 activation suggests that fractionation may be more effective in eliciting STING-interferon pathway. The effect of repeated exposure to radiation of the MN DNA has not been sufficiently studied and, in this new context, seems to be important to characterize the effect of fractionation. Studies at high doses are also missing. Many experiments using densely ionizing radiation (neutrons, $\alpha$-particles, heavy ions) have been performed, but a better characterization of cytosolic dsDNA, which can also come from very small fragments after high-LET exposure, is warranted. There are also no experiments addressing the activation of Trex 1 and STING after exposure to protons or carbon ions, currently used in particle therapy. Radiation-induced CA and MN are likely to provide important contributions to modern molecular medicine in oncology.

\section{AUTHOR'S NOTE}

The paper is the Inaugural Paper of MD as Editor of Frontiers in Oncology.

\section{AUTHOR CONTRIBUTIONS}

Both authors collected the literature and wrote the manuscript.

to ionizing radiation: comparison of the dicentric and micronucleus assays Radiat Environ Biophys (2015) 54:317-25. doi:10.1007/s00411-015-0596-3

8. Bentzen SM. From cellular to high-throughput predictive assays in radiation oncology: challenges and opportunities. Semin Radiat Oncol (2008) 18:75-88. doi:10.1016/j.semradonc.2007.10.003

9. Chua MLK, Rothkamm K. Biomarkers of radiation exposure: can they predict normal tissue radiosensitivity? Clin Oncol (2013) 25:610-6. doi:10.1016/j. clon.2013.06.010

10. Bonassi S, Znaor A, Norppa H, Hagmar L. Chromosomal aberrations and risk of cancer in humans: an epidemiologic perspective. Cytogenet Genome Res (2004) 104:376-82. doi:10.1159/000077519

11. Baumann M, Krause M, Overgaard J, Debus J, Bentzen SM, Daartz J, et al. Radiation oncology in the era of precision medicine. Nat Rev Cancer (2016) 16:234-49. doi:10.1038/nrc.2016.18

12. Rosenstein BS. Radiogenomics: identification of genomic predictors for radiation toxicity. Semin Radiat Oncol (2017) 27:300-9. doi:10.1016/j. semradonc.2017.04.005

13. Kirkwood JM, Butterfield LH, Tarhini AA, Zarour H, Kalinski P, Ferrone S. Immunotherapy of cancer in 2012. CA Cancer J Clin (2012) 62:309-35. doi:10.3322/caac. 20132

14. Jeanbart L, Swartz MA. Engineering opportunities in cancer immunotherapy. Proc Natl Acad Sci U S A (2015) 112:14467-72. doi:10.1073/pnas. 1508516112 
15. Whiteside TL, Demaria S, Rodriguez-Ruiz ME, Zarour HM, Melero I. Emerging opportunities and challenges in cancer immunotherapy. Clin Cancer Res (2016) 22:1845-55. doi:10.1158/1078-0432.CCR-16-0049

16. Weichselbaum RR, Liang H, Deng L, Fu Y-X. Radiotherapy and immunotherapy: a beneficial liaison? Nat Rev Clin Oncol (2017) 14:365-79. doi:10.1038/ nrclinonc.2016.211

17. Van Limbergen EJ, De Ruysscher DK, Olivo Pimentel V, Marcus D, Berbee M, Hoeben A, et al. Combining radiotherapy with immunotherapy: the past, the present and the future. Br J Radiol (2017) 90:20170157. doi:10.1259/bjr. 20170157

18. Ishihara D, Pop L, Takeshima T, Iyengar P, Hannan R. Rationale and evidence to combine radiation therapy and immunotherapy for cancer treatment. Cancer Immunol Immunother (2017) 66:281-98. doi:10.1007/s00262-0161914-6

19. Ngwa W, Irabor OC, Schoenfeld JD, Hesser J, Demaria S, Formenti SC. Using immunotherapy to boost the abscopal effect. Nat Rev Cancer (2018) 18(5):313-22. doi:10.1038/nrc.2018.6

20. Vatner RE, Cooper BT, Vanpouille-Box C, Demaria S, Formenti SC. Combinations of immunotherapy and radiation in cancer therapy. Front Oncol (2014) 4:325. doi:10.3389/fonc.2014.00325

21. Ebner DK, Tinganelli W, Helm A, Bisio A, Yamada S, Kamada T, et al. The immunoregulatory potential of particle radiation in cancer therapy. Front Immunol (2017) 8:99. doi:10.3389/fimmu.2017.00099

22. Durante M, Reppingen N, Held KD. Immunologically augmented cancer treatment using modern radiotherapy. Trends Mol Med (2013) 19:565-82. doi:10.1016/j.molmed.2013.05.007

23. Chen Q, Sun L, Chen ZJ. Regulation and function of the cGAS-STING pathway of cytosolic DNA sensing. Nat Immunol (2016) 17:1142-9. doi:10.1038/ ni.3558

24. Zhang X, Shi H, Wu J, Zhang X, Sun L, Chen C, et al. Cyclic GMP-AMP containing mixed phosphodiester linkages is an endogenous high-affinity ligand for STING. Mol Cell (2013) 51:226-35. doi:10.1016/j.molcel.2013.05.022

25. Gao D, Li T, Li X-D, Chen X, Li Q-Z, Wight-Carter M, et al. Activation of cyclic GMP-AMP synthase by self-DNA causes autoimmune diseases. Proc Natl Acad Sci U S A (2015) 112:E5699-705. doi:10.1073/pnas.1516465112

26. Diamond MS, Kinder M, Matsushita H, Mashayekhi M, Dunn GP, Archambault JM, et al. Type I interferon is selectively required by dendritic cells for immune rejection of tumors. JExp Med (2011) 208:1989-2003. doi:10.1084/jem.20101158

27. Fuertes MB, Kacha AK, Kline J, Woo S-R, Kranz DM, Murphy KM, et al. Host type I IFN signals are required for antitumor CD8 $+\mathrm{T}$ cell responses through CD8 $\alpha^{+}$dendritic cells. J Exp Med (2011) 208:2005-16. doi:10.1084/ jem.20101159

28. Corrales L, Matson V, Flood B, Spranger S, Gajewski TF. Innate immune signaling and regulation in cancer immunotherapy. Cell Res (2017) 27:96-108. doi:10.1038/cr.2016.149

29. Zitvogel L, Galluzzi L, Kepp O, Smyth MJ, Kroemer G. Type I interferons in anticancer immunity. Nat Rev Immunol (2015) 15:405-14. doi:10.1038/ nri3845

30. Deng L, Liang H, Xu M, Yang X, Burnette B, Arina A, et al. STING-dependent cytosolic DNA sensing promotes radiation-induced type I interferondependent antitumor immunity in immunogenic tumors. Immunity (2014) 41:843-52. doi:10.1016/j.immuni.2014.10.019

31. Vanpouille-BoxC,AlardA,AryankalayilMJ,SarfrazY,DiamondJM,Schneider RJ, et al. DNA exonuclease Trexl regulates radiotherapy-induced tumour immunogenicity. Nat Commun (2017) 8:15618. doi:10.1038/ncomms15618

32. Fischer JC, Bscheider M, Eisenkolb G, Lin C-C, Wintges A, Otten V, et al. RIG-I/MAVS and STING signaling promote gut integrity during irradiation- and immune-mediated tissue injury. Sci Transl Med (2017) 9:eaag2513. doi:10.1126/scitranslmed.aag2513

33. Liang H, Deng L, Hou Y, Meng X, Huang X, Rao E, et al. Host STINGdependent MDSC mobilization drives extrinsic radiation resistance. Nat Commun (2017) 8:1736. doi:10.1038/s41467-017-01566-5

34. Bakhoum SF, Ngo B, Laughney AM, Cavallo J-A, Murphy CJ, Ly P, et al. Chromosomal instability drives metastasis through a cytosolic DNA response. Nature (2018) 553:467-72. doi:10.1038/nature25432

35. Iurescia S, Fioretti D, Rinaldi M. Targeting cytosolic nucleic acid-sensing pathways for cancer immunotherapies. Front Immunol (2018) 9:711. doi:10.3389/ fimmu.2018.00711
36. Müller WU, Nüsse M, Miller BM, Slavotinek A, Viaggi S, Streffer C. Micronuclei: a biological indicator of radiation damage. Mutat Res (1996) 366:163-9. doi:10.1016/S0165-1110(96)90037-8

37. Fenech M. Cytokinesis-block micronucleus cytome assay. Nat Protoc (2007) 2:1084-104. doi:10.1038/nprot.2007.77

38. Cheong HSJ, Seth I, Joiner MC, Tucker JD. Relationships among micronuclei, nucleoplasmic bridges and nuclear buds within individual cells in the cytokinesis-block micronucleus assay. Mutagenesis (2013) 28:433-40. doi:10.1093/mutage/get020

39. Savage JR. Classification and relationships of induced chromosomal structural changes. J Med Genet (1976) 13:103-22. doi:10.1136/jmg.13.2.103

40. Hahnfeldt P, Hlatky LR, Brenner DJ, Sachs RK. Chromosome aberrations produced by radiation: the relationship between excess acentric fragments and dicentrics. Radiat Res (1995) 141:136-52. doi:10.2307/3579041

41. Johannes C, Horstmann M, Durante M, Chudoba I, Obe G. Chromosome intrachanges and interchanges detected by multicolor banding in lymphocytes: searching for clastogen signatures in the human genome. Radiat Res (2004) 161:540-8. doi:10.1667/RR3157

42. Cornforth MN, Durante M. Radiation quality and intra-chromosomal aberrations: size matters. Mutat Res (2018). doi:10.1016/j.mrgentox.2018. 05.002

43. Ray FA, Robinson E, McKenna M, Hada M, George K, Cucinotta F, et al. Directional genomic hybridization: inversions as a potential biodosimeter for retrospective radiation exposure. Radiat Environ Biophys (2014) 53:255-63. doi:10.1007/s00411-014-0513-1

44. Kirsch-Volders M, Tallon I, Tanzarella C, Sgura A, Hermine T, Parry EM, et al. Mitotic non-disjunction as a mechanism for in vitro aneuploidy induction by X-rays in primary human cells. Mutagenesis (1996) 11:307-13. doi:10.1093/mutage/11.4.307

45. Bakhoum SF, Kabeche L, Wood MD, Laucius CD, Qu D, Laughney AM, et al. Numerical chromosomal instability mediates susceptibility to radiation treatment. Nat Commun (2015) 6:5990. doi:10.1038/ncomms6990

46. Sgura A, Antoccia A, Cherubini R, Dalla Vecchia M, Tiveron P, Degrassi F, et al. Micronuclei, CREST-positive micronuclei and cell inactivation induced in Chinese hamster cells by radiation with different quality. Int J Radiat Biol (2000) 76:367-74. doi:10.1080/095530000138709

47. Hintzsche H, Hemmann U, Poth A, Utesch D, Lott J, Stopper H. Fate of micronuclei and micronucleated cells. Mutat Res (2017) 771:85-98. doi:10.1016/j.mrrev.2017.02.002

48. Li M, Fang X, Baker DJ, Guo L, Gao X, Wei Z, et al. The ATM-p53 pathway suppresses aneuploidy-induced tumorigenesis. Proc Natl Acad Sci U S A (2010) 107:14188-93. doi:10.1073/pnas.1005960107

49. Crasta K, Ganem NJ, Dagher R, Lantermann AB, Ivanova EV, Pan Y, et al. DNA breaks and chromosome pulverization from errors in mitosis. Nature (2012) 482:53-8. doi:10.1038/nature10802

50. Forment JV, Kaidi A, Jackson SP. Chromothripsis and cancer: causes and consequences of chromosome shattering. Nat Rev Cancer (2012) 12:663-70. doi:10.1038/nrc3352

51. Leibowitz ML, Zhang C-Z, Pellman D. Chromothripsis: a new mechanism for rapid karyotype evolution. Annu Rev Genet (2015) 49:183-211. doi:10.1146/ annurev-genet-120213-092228

52. Samwer M, Schneider MWG, Hoefler R, Schmalhorst PS, Jude JG, Zuber J, et al. DNA cross-bridging shapes a single nucleus from a set of mitotic chromosomes. Cell (2017) 170:956-72.e23. doi:10.1016/j.cell.2017.07.038

53. Zhang C-Z, Spektor A, Cornils H, Francis JM, Jackson EK, Liu S, et al. Chromothripsis from DNA damage in micronuclei. Nature (2015) 522: 179-84. doi:10.1038/nature14493

54. Harding SM, Benci JL, Irianto J, Discher DE, Minn AJ, Greenberg RA. Mitotic progression following DNA damage enables pattern recognition within micronuclei. Nature (2017) 548:466-70. doi:10.1038/nature23470

55. MacKenzie KJ, Carroll P, Martin CA, Murina O, Fluteau A, Simpson DJ, et al. CGAS surveillance of micronuclei links genome instability to innate immunity. Nature (2017) 548:461-5. doi:10.1038/nature23449

56. Hatch EM, Fischer AH, Deerinck TJ, Hetzer MW. Catastrophic nuclear envelope collapse in cancer cell micronuclei. Cell (2013) 154:47-60. doi:10.1016/j. cell.2013.06.007

57. Vanpouille-Box C, Formenti SC, Demaria S. Toward precision radiotherapy for use with immune checkpoint blockers. Clin Cancer Res (2018) 24:259-65. doi:10.1158/1078-0432.CCR-16-0037 
58. Kagawa N, Shimura M, Takai A, Endo S, Fujikawa K. Relative biological effectiveness of fission neutrons for induction of micronucleus formation in mouse reticulocytes in vivo. Mutat Res (2004) 556:93-9. doi:10.1016/j. mrfmmm.2004.07.001

59. Litvinchuk AV, Vachelová J, Michaelidesová A, Wagner R, Davídková M. Dose-dependent micronuclei formation in normal human fibroblasts exposed to proton radiation. Radiat Environ Biophys (2015) 54:327-34. doi:10.1007/s00411-015-0598-1

60. Green LM, Murray DK, Bant AM, Kazarians G, Moyers MF, Nelson GA, et al. Response of thyroid follicular cells to gamma irradiation compared to proton irradiation. I. Initial characterization of DNA damage, micronucleus formation, apoptosis, cell survival, and cell cycle phase redistribution. Radiat Res (2001) 155:32-42. doi:10.1667/0033-7587(2001)155[0032:ROTFCT]2.0.CO;2

61. Bilbao A, Prosser JS, Edwards AA, Moody JC, Lloyd DC. The induction of micronuclei in human lymphocytes by in vitro irradiation with alpha particles from plutonium-239. Int J Radiat Biol (1989) 56:287-92. doi:10.1080/ 09553008914551451

62. Pathak R, Dey SK, Sarma A, Khuda-Bukhsh AR. Cell killing, nuclear damage and apoptosis in Chinese hamster V79 cells after irradiation with heavy-ion beams of 16O, 12C and 7Li. Mutat Res (2007) 632:58-68. doi:10.1016/j.mrgentox. 2007.04.007

63. Snijders AM, Mannion BJ, Leung SG, Moon SC, Kronenberg A, Wiese C. Micronucleus formation in human keratinocytes is dependent on radiation quality and tissue architecture. Environ Mol Mutagen (2015) 56:22-31. doi:10.1002/em.21887

64. Hirayama R, Uzawa A, Obara M, Takase N, Koda K, Ozaki M, et al. Determination of the relative biological effectiveness and oxygen enhancement ratio for micronuclei formation using high-LET radiation in solid tumor cells: an in vitro and in vivo study. Mutat Res Genet Toxicol Environ Mutagen (2015) 793:41-7. doi:10.1016/j.mrgentox.2015.08.003

65. Desai N, Sodolak J, Gersey B, Durante M, Lin ZW, Rusek A, et al. In vitro $\mathrm{H} 2 \mathrm{AX}$ phosphorylation and micronuclei induction in human fibroblasts across the Bragg curve of a $577 \mathrm{MeV} /$ nucleon Fe incident beam. Radiat Meas (2006) 41:1209-15. doi:10.1016/j.radmeas.2006.04.031

66. Takatsuji T, Takayanagi H, Morishita K, Nojima K, Furusawa Y, Nakazawa Y, et al. Induction of micronuclei in germinating onion seed root tip cells irradiated with high energy heavy ions. J Radiat Res (2010) 51:315-23. doi:10.1269/ jrr.09028

67. Helm A, Lee R, Durante M, Ritter S. The influence of C-ions and X-rays on human umbilical vein endothelial cells. Front Oncol (2016) 6:5. doi:10.3389/ fonc.2016.00005

68. Ritter S, Durante M. Heavy-ion induced chromosomal aberrations: a review. Mutat Res (2010) 701:38-46. doi:10.1016/j.mrgentox.2010.04.007

69. Kiefer J. Mutagenic effects of heavy charged particles. J Radiat Res (2002) 43:S21-5. doi:10.1269/jrr.43.S21

70. Friedrich T, Scholz U, Elsässer T, Durante M, Scholz M. Systematic analysis of RBE and related quantities using a database of cell survival experiments with ion beam irradiation. J Radiat Res (2013) 54:494-514. doi:10.1093/jrr/rrs114

71. Yang TC, Craise LM, Mei MT, Tobias CA. Neoplastic cell transformation by heavy charged particles. Radiat Res Suppl (1985) 8:S177-87. doi: $10.2307 / 3583525$

72. Graupner A, Eide DM, Brede DA, Ellender M, Lindbo Hansen E, Oughton DH, et al. Genotoxic effects of high dose rate X-ray and low dose rate gamma radiation in Apc Min/+ mice. Environ Mol Mutagen (2017) 58:560-9. doi:10.1002/ em. 22121

73. Sorensen KJ, Zetterberg LA, Nelson DO, Grawe J, Tucker JD. The in vivo dose rate effect of chronic gamma radiation in mice: translocation and micronucleus analyses. Mutat Res (2000) 457:125-36. doi:10.1016/S0027-5107(00)00136-6

74. Lee TK, O’Brien KF, Naves JL, Christie KI, Arastu HH, Eaves GS, et al. Micronuclei in lymphocytes of prostate cancer patients undergoing radiation therapy. Mutat Res (2000) 469:63-70. doi:10.1016/S1383-5718(00)00072-3

75. Tichy A, Kabacik S, O’Brien G, Pejchal J, Sinkorova Z, Kmochova A, et al. The first in vivo multiparametric comparison of different radiation exposure biomarkers in human blood. PLoS One (2018) 13:e0193412. doi:10.1371/ journal.pone.0193412

76. Unal D, Kiraz A, Avci D, Tasdemir A, Unal TD, Cagli S, et al. Cytogenetic damage of radiotherapy in long-term head and neck cancer survivors. Int J Radiat Biol (2016) 92:364-70. doi:10.1080/09553002.2016.1175680
77. Werbrouck J, Ost P, Fonteyne V, De Meerleer G, De Neve W, Bogaert E, et al. Early biomarkers related to secondary primary cancer risk in radiotherapy treated prostate cancer patients: IMRT versus IMAT. Radiother Oncol (2013) 107:377-81. doi:10.1016/j.radonc.2013.05.014

78. Depuydt J, Baeyens A, Barnard S, Beinke C, Benedek A, Beukes P, et al. RENEB intercomparison exercises analyzing micronuclei (cytokinesis-block micronucleus assay). Int J Radiat Biol (2017) 93:36-47. doi:10.1080/09553002. 2016.1206231

79. Hoffmann GR, Sayer AM, Littlefield LG. Higher frequency of chromosome aberrations in late-arising first-division metaphases than in early-arising metaphases after exposure of human lymphocytes to X-rays in G 0 . Int J Radiat Biol (2002) 78:765-72. doi:10.1080/09553000210152962

80. Lee R, Nasonova E, Hartel C, Durante M, Ritter S. Chromosome aberration measurements in mitotic and G 2-PCC lymphocytes at the standard sampling time of $48 \mathrm{~h}$ underestimate the effectiveness of high-LET particles. Radiat Environ Biophys (2011) 50:371-81. doi:10.1007/s00411-011-0360-2

81. Durante M, Furusawa Y, Majima H, Kawata T, Gotoh E. Association between G2-phase block and repair of radiation-induced chromosome fragments in human lymphocytes. Radiat Res (1999) 151:670-6. doi:10.2307/ 3580205

82. Johannes C, Dixius A, Pust M, Hentschel R, Buraczewska I, Staaf E, et al. The yield of radiation-induced micronuclei in early and late-arising binucleated cells depends on radiation quality. Mutat Res (2010) 701:80-5. doi:10.1016/j. mrgentox.2010.05.005

83. Lo SS, Fakiris AJ, Chang EL, Mayr NA, Wang JZ, Papiez L, et al. Stereotactic body radiation therapy: a novel treatment modality. Nat Rev Clin Oncol (2010) 7:44-54. doi:10.1038/nrclinonc.2009.188

84. Desai NB, Laine AM, Timmerman RD. Stereotactic ablative body radiotherapy (SAbR) for oligometastatic cancer. Br J Radiol (2017) 90:20160500. doi:10.1259/bjr.20160500

85. Lo SS, Teh BS, Lu JJ, Schefter TE. Stereotactic Body Radiation Therapy. Berlin, Heidelberg: Springer-Verlag (2012). doi:10.1007/978-3-642-25605-9

86. Durante M, Orecchia R, Loeffler JS. Charged-particle therapy in cancer: clinical uses and future perspectives. Nat Rev Clin Oncol (2017) 14:483-95. doi:10.1038/nrclinonc. 2017.30

87. Loeffler JS, Durante M. Charged particle therapy - optimization, challenges and future directions. Nat Rev Clin Oncol (2013) 10:411-24. doi:10.1038/ nrclinonc. 2013.79

88. Durante M, Cucinotta FA, Loeffler JS, editors. Charged Particles in Oncology. Lausanne, Switzerland: Frontiers Media SA (2018).

89. Bernstein MB, Krishnan S, Hodge JW, Chang JY. Immunotherapy and stereotactic ablative radiotherapy (ISABR): a curative approach? Nat Rev Clin Oncol (2016) 13:516-24. doi:10.1038/nrclinonc.2016.30

90. Durante M, Brenner DJ, Formenti SC. Does heavy ion therapy work through the immune system? Int J Radiat Oncol Biol Phys (2016) 96:934-6. doi:10.1016/j.ijrobp.2016.08.037

91. Walshaw RC, Honeychurch J, Illidge TM. Stereotactic ablative radiotherapy and immunotherapy combinations: turning the future into systemic therapy? Br J Radiol (2016) 89:20160472. doi:10.1259/bjr.20160472

92. Demaria S, Formenti SC. Radiation as an immunological adjuvant: current evidence on dose and fractionation. Front Oncol (2012) 2:153. doi:10.3389/ fonc.2012.00153

93. Formenti SC. Optimizing dose per fraction: a new chapter in the story of the abscopal effect? Int J Radiat Oncol Biol Phys (2017) 99:677-9. doi:10.1016/j. ijrobp.2017.07.028

94. Dewan MZ, Galloway AE, Kawashima N, Dewyngaert JK, Babb JS, Formenti SC, et al. Fractionated but not single-dose radiotherapy induces an immune-mediated abscopal effect when combined with anti-CTLA-4 antibody. Clin Cancer Res (2009) 15:5379-88. doi:10.1158/1078-0432. CCR-09-0265

95. Schaue D, Ratikan JA, Iwamoto KS, McBride WH. Maximizing tumor immunity with fractionated radiation. Int J Radiat Oncol Biol Phys (2012) 83:1306-10. doi:10.1016/j.ijrobp.2011.09.049

96. de Oliveira Mann CC, Kranzusch PJ. cGAS conducts micronuclei DNA surveillance. Trends Cell Biol (2017) 27:697-8. doi:10.1016/j.tcb.2017.08.007

97. Maciejowski J, Li Y, Bosco N, Campbell PJ, de Lange T. Chromothripsis and kataegis induced by telomere crisis. Cell (2015) 163:1641-54. doi:10.1016/j. cell.2015.11.054 
98. Vanpouille-Box C, Formenti SC, Demaria S. TREX1 dictates the immune fate of irradiated cancer cells. Oncoimmunology (2017) 6:e1339857. doi:10.1080/ 2162402X.2017.1339857

99. Li X, Shu C, Yi G, Chaton CT, Shelton CL, Diao J, et al. Cyclic GMP-AMP synthase is activated by double-stranded DNA-induced oligomerization. Immunity (2013) 39:1019-31. doi:10.1016/j.immuni.2013.10.019

100. Lee A, Park E-B, Lee J, Choi B-S, Kang S-J. The N terminus of cGAS deoligomerizes the cGAS: DNA complex and lifts the DNA size restriction of corecGAS activity. FEBS Lett (2017) 591:954-61. doi:10.1002/1873-3468.12598

101. Vral A, Verhaegen F, Thierens H, De Ridder L. Micronuclei induced by fast neutrons versus 60Co gamma-rays in human peripheral blood lymphocytes. Int J Radiat Biol (1994) 65:321-8. doi:10.1080/09553009414550381

102. Suzuki K, Mori A, Ishii KJ, Saito J, Singer DS, Klinman DM, et al. Activation of target-tissue immune-recognition molecules by double-stranded polynucleotides. Proc Natl Acad Sci U S A (1999) 96:2285-90. doi:10.1073/pnas. 96.5.2285

103. Kawashima A, Tanigawa K, Akama T, Wu H, Sue M, Yoshihara A, et al. Fragments of genomic DNA released by injured cells activate innate immunity and suppress endocrine function in the thyroid. Endocrinology (2011) 152:1702-12. doi:10.1210/en.2010-1132

104. Holley WR, Chatterjee A. Clusters of DNA induced by ionizing radiation: formation of short DNA fragments. I. Theoretical modeling. Radiat Res (1996) 145:188-99. doi:10.2307/3579174

105. Rydberg B. Clusters of DNA damage induced by ionizing radiation: formation of short DNA fragments. II. Experimental detection. Radiat Res (1996) 145:200-9. doi:10.2307/3579175

106. Höglund E, Blomquist E, Carlsson J, Stenerlöw B. DNA damage induced by radiation of different linear energy transfer: initial fragmentation. Int J Radiat Biol (2000) 76:539-47. doi:10.1080/095530000138556

107. Pang D, Chasovskikh S, Rodgers JE, Dritschilo A. Short DNA fragments are a hallmark of heavy charged-particle irradiation and may underlie their greater therapeutic efficacy. Front Oncol (2016) 6:130. doi:10.3389/fonc.2016.00130

108. Campa A, Ballarini F, Belli M, Cherubini R, Dini V, Esposito G, et al. DNA DSB induced in human cells by charged particles and gamma rays: experimental results and theoretical approaches. Int J Radiat Biol (2005) 81:841-54. doi:10.1080/09553000500530888

109. Wang H, Wang X, Zhang P, Wang Y. The Ku-dependent non-homologous end-joining but not other repair pathway is inhibited by high linear energy transfer ionizing radiation. DNA Repair (Amst) (2008) 7:725-33. doi:10.1016/j.dnarep.2008.01.010

110. Wang H, Wang Y. Heavier ions with a different linear energy transfer spectrum kill more cells due to similar interference with the Ku-dependent DNA repair pathway. Radiat Res (2014) 182:458-61. doi:10.1667/RR13857.1

111. Ungricht R, Kutay U. Mechanisms and functions of nuclear envelope remodelling. Nat Rev Mol Cell Biol (2017) 18:229-45. doi:10.1038/nrm.2016.153

112. Yang Z, Maciejowski J, de Lange T. Nuclear envelope rupture is enhanced by loss of p53 or Rb. Mol Cancer Res (2017) 15:1579-86. doi:10.1158/1541-7786. MCR-17-0084

113. Raab M, Gentili M, de Belly H, Thiam HR, Vargas P, Jimenez AJ, et al. ESCRT III repairs nuclear envelope ruptures during cell migration to limit DNA damage and cell death. Science (2016) 352:359-62. doi:10.1126/science. aad7611

114. Denais CM, Gilbert RM, Isermann P, McGregor AL, te Lindert M, Weigelin B, et al. Nuclear envelope rupture and repair during cancer cell migration. Science (2016) 352:353-8. doi:10.1126/science.aad7297
115. Moncharmont C, Levy A, Guy J-B, Falk AT, Guilbert M, Trone J-C, et al. Radiation-enhanced cell migration/invasion process: a review. Crit Rev Oncol Hematol (2014) 92:133-42. doi:10.1016/j.critrevonc.2014.05.006

116. Vilalta M, Rafat M, Graves EE. Effects of radiation on metastasis and tumor cell migration. Cell Mol Life Sci (2016) 73:2999-3007. doi:10.1007/ s00018-016-2210-5

117. Rieken S, Rieber J, Brons S, Habermehl D, Rief H, Orschiedt L, et al. Radiation-induced motility alterations in medulloblastoma cells. J Radiat Res (2015) 56:430-6. doi:10.1093/jrr/rru120

118. Young AGH, Bennewith KL. Ionizing radiation enhances breast tumor cell migration in vitro. Radiat Res (2017) 188:381-91. doi:10.1667/RR14738.1

119. Imaizumi H, Sato K, Nishihara A, Minami K, Koizumi M, Matsuura N, et al. $\mathrm{X}$-ray-enhanced cancer cell migration requires the linker of nucleoskeleton and cytoskeleton complex. Cancer Sci (2018) 109(4):1158-65. doi:10.1111/ cas. 13545

120. Hatch EM, Hetzer MW. Nuclear envelope rupture is induced by actinbased nucleus confinement. J Cell Biol (2016) 215:27-36. doi:10.1083/ jcb. 201603053

121. White MJ, McArthur K, Metcalf D, Lane RM, Cambier JC, Herold MJ, et al. Apoptotic caspases suppress mtDNA-induced STING-mediated type I IFN production. Cell (2014) 159:1549-62. doi:10.1016/j.cell.2014.11.036

122. Rongvaux A, Jackson R, Harman CCD, Li T, West AP, De Zoete MR, et al. Apoptotic caspases prevent the induction of type I interferons by mitochondrial DNA. Cell (2014) 159:1563-77. doi:10.1016/j.cell.2014.11.037

123. Szumiel I. Ionizing radiation-induced oxidative stress, epigenetic changes and genomic instability: the pivotal role of mitochondria. Int J Radiat Biol (2015) 91:1-12. doi:10.3109/09553002.2014.934929

124. Kam WW-Y, Banati RB. Effects of ionizing radiation on mitochondria. Free Radic Biol Med (2013) 65:607-19. doi:10.1016/j.freeradbiomed.2013.07.024

125. Prise KM, O’Sullivan JM. Radiation-induced bystander signalling in cancer therapy. Nat Rev Cancer (2009) 9:351-60. doi:10.1038/nrc2603

126. Yang G, Wu L, Chen S, Zhu L, Huang P, Tong L, et al. Mitochondrial dysfunction resulting from loss of cytochrome c impairs radiation-induced bystander effect. Br J Cancer (2009) 100:1912-6. doi:10.1038/sj.bjc.6605087

127. Friedland W, Schmitt E, Kundrát P, Baiocco G, Ottolenghi A. Track-structure simulations of energy deposition patterns to mitochondria and damage to their DNA. Int J Radiat Biol (2018) 1-9. doi:10.1080/09553002.2018. 1450532

128. Walsh DWM, Siebenwirth C, Greubel C, Ilicic K, Reindl J, Girst S, et al. Live cell imaging of mitochondria following targeted irradiation in situ reveals rapid and highly localized loss of membrane potential. Sci Rep (2017) 7:1-11. doi: $10.1038 /$ srep46684

Conflict of Interest Statement: The authors declare that the research was conducted in the absence of any commercial or financial relationships that could be construed as a potential conflict of interest.

The reviewer HL and handling Editor declared their shared affiliation.

Copyright (C) 2018 Durante and Formenti. This is an open-access article distributed under the terms of the Creative Commons Attribution License (CC BY). The use, distribution or reproduction in other forums is permitted, provided the original author(s) and the copyright owner are credited and that the original publication in this journal is cited, in accordance with accepted academic practice. No use, distribution or reproduction is permitted which does not comply with these terms. 